\title{
A Review Analysis on Reform New Visa (e-Tourist Visa) Policy to Encourage FTAS in India
}

\author{
Dinesh K. Jayswal ${ }^{1}$, Dr. Mona Jaiswal ${ }^{2}$ \\ ${ }^{1,2}$ Government Women`s Polytechnic College Jabalpur, India
}

\begin{abstract}
India has become the fastest growing tourist destination for international tourists in South Asia. The share of Travel and Tourism in the India"s GDP in 2013 was INR 2,178.1 Billion. In 2014, this contribution is expected to soar by 7.5\% to INR 2,341.45 Billion. Due to the direct impact of this sector in the Economy, the Govt. of India has introduced many initiatives, such as Visit India Year 2009, Incredible India and Atithi Devo Bhava to attract foreign tourists, but the introducing e-Tourist Visa, Foreign Tourist Arrivals (FTAs) has remarkable growth during 2014-15. GOI has launched initially Tourist Visa on Arrival (TVOA) in January 2010. To make TVOA easier and hassle free and encourage Foreign Tourist Arrivals (FTAs), India has introduced Visa on Arrival (VoA) enabled by Electronic Travel Authorization (ETA) in November 27, 2014 and implemented an online method facility for tourists. In April 2015 this „Visa on Arrival" scheme was renamed to ,e-Tourist Visa (e-TV). "This resulted 6.8\% growth in Foreign Tourist Arrivals in January 2016 over the same period in 2015 and Rs. 13,669 crores Foreign exchange earned through Tourism in January 2016. Here by this paper the main aims to discuss the present Govt."s e-Tourist Visa (e-TV) policy and its impact of encouraging Foreign Tourist Arrivals (FTAs) in the country to boost inbound tourism.
\end{abstract}

Keywords: GDP, Visa on Arrival, Incredible India, FTAs, e-Tourist Visa, Inbound tourism.

\section{Introduction}

The travel and tourism industry has emerged as one of the largest and fastest growing economic sectors globally. Much of its growth is due to higher disposable incomes, increased leisure time and falling costs of tourism activities. For 2015, UNWTO forecasts international tourist arrivals to grow between $3 \%$ and $4 \%$ and the total number of tourists travelled abroad more than one billion (1,138 million) in 2014. In this context UNWTO celebrated the World Tourism Day on $27^{\text {th }}$ September under the theme for 2015: “One Billion Tourists, One Billion Opportunities”. This year's theme emphasizes the impact of the tourism sector on economic growth, job creation and development (UNWTO).

Under this vision of the world tourists ' movement, India has became the fastest growing tourist destination for international tourists in South Asia. The share of Travel and Tourism in the India's GDP in 2013 was INR 2,178.1 Billion. In 2014, this contribution is expected to soar by $7.5 \%$ to INR 2,341.45 Billion ${ }^{[1]}$. To attract and encourage Foreign Tourist Arrivals in India for promotion of Indian tourism, India has introduced Visa on Arrival (VoA) enabled by Electronic Travel Authorization (ETA) in November 27, 2014 and implemented an online method facility for tourists. In April 2015 this Visa on Arrival scheme was renamed to 'e-Tourist Visa (e-TV)." This resulted 6.8\% growth in Foreign Tourist Arrivals in January 2016 over the same period in 2015 and Rs. 13,669 crores Foreign exchange earned through Tourism in January $2016^{[2]}$.

\section{Objectives and Methodology}

The main objectives of the study are as follows:

1) To study about Indian Visa Policy and its provisions of issuance.

2) To examine the factors encouraging for growth of women in the tourism industry. 3.

3) To analyze the impact of e-Tourist Visa on Foreign Tourists Arrivals (FTAs) in 2015 as comparison to Tourist Visa on Arrival (TVoA) in 2014.

This study is based on secondary sources of data by newspapers, economic magazines, tourism websites, government reports, internet sources and review of some selected research articles etc.

\section{Review of Literature}

\section{Indian Visa}

According to official definition, $A$ visa is an entry in a passport or any other travel document made by a government official, indicating that the holder has been granted permission to enter or re-enter the country concert." ${ }^{[3]}$ An Indian VISA is "an endorsement on a passport of a foreign national or non-citizen of India indicating that the holder is allowed to enter, leave, or stay for a specified period of time in the country." It a form of permission for a non-citizen to travel to, enter, transit or remain in a particular country. A visa does not guarantee entry that remains the right of the immigration officials of the country concerned. 


\section{International Journal of Science and Research (IJSR) \\ ISSN (Online): 2319-7064}

Index Copernicus Value (2013): 6.14 | Impact Factor (2014): 5.611

Some major type of Indian Visa \& provisions of issuance-

\begin{tabular}{|c|c|c|c|c|c|}
\hline $\begin{array}{l}\text { Sr. } \\
\text { No. }\end{array}$ & Type of Visa & $\begin{array}{l}\text { Period for which } \\
\text { granted }\end{array}$ & $\begin{array}{l}\text { Entry (Single-S, } \\
\text { Multi-M, Double) }\end{array}$ & $\begin{array}{l}\text { Documents required with } \\
\text { application }\end{array}$ & $\begin{array}{l}\text { Extendable } \\
\text { in India? }\end{array}$ \\
\hline 1 & Tourist visa & 180 days & $\mathrm{M}$ & $\begin{array}{l}\text { Proof regarding assured financial standing i.e. return ticket } \\
\text { and availability of sufficient money to spend during stay in } \\
\text { India. }\end{array}$ & No \\
\hline 2 & Transit visa & 15 days & $\mathrm{S}$ & Confirmed onward journey ticket. & No \\
\hline 3 & Business visa & Up to 5 years & $\mathrm{M}$ & $\begin{array}{l}\text { Documents to prove bonafide purpose (Company's letter, } \\
\text { etc.), proof of financial standing. }\end{array}$ & Yes \\
\hline 4 & $\begin{array}{l}\text { Employment } \\
\text { visa }\end{array}$ & $\begin{array}{l}2 \text { years* or period of } \\
\text { Contract, whichever } \\
\text { is less }\end{array}$ & $\mathrm{M}$ & $\begin{array}{l}\text { Proof of employment (appointment document), terms and } \\
\text { conditions \& conditions. }\end{array}$ & Yes \\
\hline 5 & Student visa & $\begin{array}{l}5 \text { years or Period of } \\
\text { Course, whichever is } \\
\text { less }\end{array}$ & \begin{tabular}{|c|}
$\begin{array}{c}3- \\
\text { Entries/Academic } \\
\text { year }\end{array}$ \\
\end{tabular} & $\begin{array}{c}\text { Proof of admission in Indian Institution, letter of support } \\
\text { from parent/guardian accompanied by a bank } \\
\text { guarantee/certificate regarding financial standing }\end{array}$ & Yes \\
\hline 6 & $\begin{array}{l}\mathrm{X}^{6} \text { (Entry) visa } \\
- \text { for Foreigners } \\
\text { of Indian Origin }\end{array}$ & 5 years & $\mathrm{M}$ & Proof of being of Indian Origin. & Yes \\
\hline
\end{tabular}

1) Up to 5 years in the case of a foreign technician/expert coming in pursuance of a bilateral agreement between Government of India and foreign government/collaboration agreement approved by Government of India.

2) Up to 3 years in the case of highly skilled foreign personnel being employed in the IT software and IT enabled sectors.

\section{Tourist Visa}

A Tourist Visa is granted for visiting India for recreation, sight-seeing, casual visits to meet friends and relatives etc. No other activities are permissible on a Tourist Visa. Tourist Visa can only be granted to a foreigner who does not have a residence or occupation in India and whose sole objective of visiting India is recreation, sightseeing, casual visit to meet friends and relatives etc.

\section{Eligibility to apply for Indian Visa -}

A tourist visa is appropriate for those who would like to visit India for tourism or other non-business related purposes. The following persons are not eligible to apply for a tourist visa and they must apply for the Entry Visa:

- Persons of Indian Origin.

- Spouse and children of a person of Indian origin.

- Spouse and dependent family members of a foreign national coming to India on a long term visa such as Employment Visa, Business Visa, Research Visa or Student Visa.

\section{Validity}

For U.S. citizens: U.S. citizens can get a 6-month, 5-year or 10 -year tourist visa under a bilateral agreement.

Non-U.S. citizens: Non-U.S. citizens are only eligible for up to a six-month tourist visa.

The visa validity duration begins on the first day of issuance. Therefore, a six-month visa issued on July 1 would be valid until December 31. Extension of stay is not granted on tourist visas and it can not be converted into any other visa [4]

\section{New Visa policy of India:}

In order to boost numbers of foreign tourist arrival in India, the Indian Government decided to implement a new visa policy, allowing visitors to obtain a visa on arrival (VOA) at 16 designated international airports by obtaining an Electronic Travel Authorization (ETA) online before arrival without the need to visit an Indian consulate or visa centre. Currently the requirements of obtaining India Visa for foreign nationals are as follows:

1. Visa not required - Nationals of Bhutan, Maldives and Nepal do not require a visa.

2. Visa not requires for diplomatic or official passports Holders of -

a. Diplomatic or official passports of the following countries - Argentina, Bangladesh, Belarus, Brazil, Bulgaria, Cambodia, Chile, Croatia, Ecuador, Denmark, Colombia, Cyprus, Egypt, El Salvador, Guyana, Honduras, Hungary, Indonesia, Israel, Kazakhstan, Kyrgyzstan, Laos, Malaysia, Mauritius, Mexico, Mongolia, Myanmar, Namibia, Nicaragua, Paraguay, Peru, Philippines, Russia, Serbia, Singapore, South Africa, South Korea, Sri Lanka, Syria, Tajikistan, Thailand, Uruguay, Venezuela and Vietnam.

b. Diplomatic passports only of the following countries - Armenia, France, Germany, Greece, Japan, Lithuania, Macedonia, Malta, Norway, Romania, Turkey, Turkmenistan and Ukraine.

3. Visa fees not required - Citizens of Afghanistan, Argentina, Bangladesh, DPR Korea, Jamaica, Maldives, Mauritius, Mongolia, Nepal, South Africa and Uruguay are not required to pay a fee when obtaining Indian visa [5].

\section{Tourist Visa on Arrival (TVOA) Scheme:}

Government of India has launched the Tourist Visa on Arrival (TVOA) Scheme initially, in January 2010. This Scheme was introduced for citizens of five countries, namely Finland, Japan, Luxembourg, New Zealand and Singapore. In January 2011, the TVOA Scheme was extended to citizens of six more countries, viz. Cambodia, Vietnam, Philippines, Laos, Indonesia or Myanmar. 


\section{International Journal of Science and Research (IJSR) \\ ISSN (Online): 2319-7064 \\ Index Copernicus Value (2013): 6.14 | Impact Factor (2014): 5.611}

The main objective of the TOVA scheme is to attract more foreign tourists and to encourage them to plan their travel to India at a short notice.

\section{Reform E-Tourist Visa:}

On November 27, 2014, India introduced its Visa on Arrival enabled by Electronic Travel Authorization (ETA) facility for tourists and business visitors and implemented an online method for citizens of 40 countries to apply and receive Tourist Visa. In April 2015 this Visa on Arrival ee $^{\text {scheme }}$ was renamed to ' $\boldsymbol{e}$-Tourist Visa $(\boldsymbol{e}-\boldsymbol{T V})^{\text {ee }}$ in order to avoid confusion.

The scheme was extended to the citizens of Guyana and Sri Lanka in January, 2015 and April, 2015 respectively. The eTourist Visa facility was further extended to the nationals of 31 countries in June, $2015^{[6]}$.

\section{Countries/territories for which Indian $e-T V$ facility is available -}

Last year on November 27, the government launched the Tourist Visa on Arrival (TVoA) enabled by Electronic Travel Authorization (ETA), known as e-Tourist Visa for tourists from 113 countries at 16 big and small airports around the country ${ }^{[7]}$. Government plan to raise this facility to 150 countries and next it will be made available to citizens of about 180 countries in several phases ${ }^{[8]}$. Presently e-Tourist Visa Facility is available for holders of passport of following countries/territories:
Andorra, Anguilla, Antigua \& Barbuda, Argentina, Armenia, Aruba, Australia, Bahamas, Barbados, Belgium, Belize, Bolivia, Brazil, Cambodia, Canada, Cayman Island, Chile, China, China- SAR Hong Kong, China- SAR Macau, Colombia, Cook Islands, Costa Rica, Cuba, Djibouti, Dominica, Dominican Republic, East Timor, Ecuador, El Salvador, Estonia, Fiji, Finland, France, Georgia, Germany, Grenada, Guatemala, Guyana, Haiti, Honduras, Hungary, Indonesia, Ireland, Israel, Jamaica, Japan, Jordan, Kenya, Kiribati, Laos, Latvia, Liechtenstein, Lithuania, Luxembourg, Malta, Malaysia, Marshall Islands, Mauritius, Mexico, Micronesia, Monaco, Mongolia, Montenegro, Montserrat, Mozambique, Myanmar, Nauru, Netherlands, New Zealand, Nicaragua, Niue Island, Norway, Oman, Palau, Palestine, Panama, Papua New Guinea, Paraguay, Peru, Philippines, Poland, Portugal, Republic of Korea, Republic of Macedonia, Russia, Saint Christopher and Nevis, Saint Lucia, Saint Vincent \& the Grenadines, Samoa, Seychelles, Singapore, Slovenia, Solomon Islands, Spain, Sri Lanka, Suriname, Sweden, Taiwan, Tanzania, Thailand, Tonga, Turks \& Caicos Island, Tuvalu, UAE, Ukraine, United Kingdom, USA, Uruguay, Vanuatu, Vatican CityHoly See, Venezuela, Vietnam.

\section{E-Tourist Visa Application Process -}

A foreign citizen of any above mentioned country/territory can follow the four easy steps to obtain e-tourist visa for visiting India. These 4 steps are:
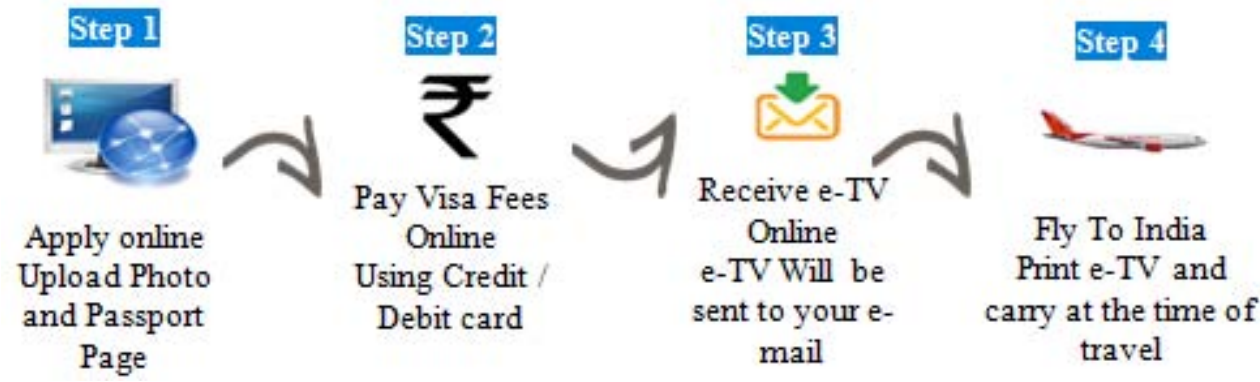

Eligibility for foreign nationals to getting Indian ETourist Visa -

The citizens of foreign nationals can obtain Indian e-TV, if they have the following eligibilities:

1) International Travellers whose sole objective of visiting India is recreation, sightseeing, casual visit to meet friends or relatives, short duration medical treatment or casual business visit.

2) Passport should have at least 6 months validity from the date of arrival in India. The passport should have at least two blank pages for stamping by the Immigration Officer.

3) International Travellers should have return ticket or onward journey ticket, with sufficient money to spend during his/her stay in India.

4) International Travellers having Pakistani Passport or Pakistani origin may please apply for regular Visa at Indian Mission.

5) Not available to Diplomatic/Official Passport Holders.

6) Not available to individuals endorsed on Parent's/Spouse's Passport i.e. each individual should have a separate passport.

7) Not available to International Travel Document Holders ${ }^{[9]}$.

\section{Availability of E-Tourist Visa -}

Visitors to India must obtain a visa from an Indian diplomatic mission unless they come from one of the visaexempt countries or a country whose citizens may obtain a visa online. After online process the citizen of foreign nationals can obtain the Indian visa by arrive at 16 International airports located in different Indian cities ${ }^{[\mathbf{1 0}]}$. E-Tourist Visa allows arrival at the following 16 airports:

\section{Airports IATA Code}

1. Sardar ballabh bhai Patel International Airport, Ahamdabad (Guj.) AMD

2. Sri Guru Ram Dass Jee International Airport, Amritsar (Punjab) ATQ

3. Indira Gandhi International Airport, Delhi DEL 


\section{International Journal of Science and Research (IJSR) \\ ISSN (Online): 2319-7064}

Index Copernicus Value (2013): 6.14 | Impact Factor (2014): 5.611

4. Kempegowda International Airport, Bengluru (Karnataka) BLR

5. Chennai International Airport, Chennai (Tamil Nadu) MAA

6. Gaya Airport, Bodhgaya (Bihar) GAY

7. Goa International Airport, Goa GOI

8. Jaipur International Airport, Jaipur (Rajasthan) JAI

9. Cochin International Airport, Kochi COK

10. Netaji Subhas Chandra Bose International Airport, Kolkata(WB) CCU

11. Chaudhary Charan Singh International Airport, Lucknow(UP) LKO

12. Chhatrapati Shivaji International Airport, Mumbai(MH) BOM

13. Rajiv Gandhi International Airport, Hyderabad (AP) HYD

14. Trivandrum International Airport, Thiruvananthpuram (Kerala) TRV

15. Tiruchirappalli (or Trichy)International Airport, Tiruchi TRZ

16. Lal Bahadur Shastri International Airport, Varanasi (UP) VNS

Impact on FTAs in India of Reform e-Tourist Visa:

In order to boost tourism numbers, the Indian Government decided to implement a new visa policy, allowing visitors to obtain a visa on arrival at above listed 16 designated international airports by obtaining an Electronic Travel Authorization online before arrival without the need to visit an Indian consulate or visa centre.

In the Following table, data shows the continuously growth of foreign tourist arrivals in January-December 2015 as comparison to January -December 2014

Table 1: FTAs* Month-wise data on TVoA and e-TV during 2014-15

\begin{tabular}{|c|c|c|c|c|}
\hline $\begin{array}{c}\text { FTAs in } \\
(2014-15)\end{array}$ & $\begin{array}{c}\text { FTAs on } \\
\text { TVoA/ } \\
\text { e-TV in 2014 }\end{array}$ & $\begin{array}{c}\text { FTAs on e- } \\
\text { TV in 2015 }\end{array}$ & $\begin{array}{c}\text { FTAs on e- } \\
\text { TV in Jan- } \\
2016\end{array}$ & $\begin{array}{c}\text { Growth \% } \\
(2014-15)\end{array}$ \\
\hline January & 1,903 & 25,023 & $\begin{array}{c}88,162 \\
(253.3)^{* *}\end{array}$ & 1214.9 \\
\hline February & 1,980 & 24,985 & - & 1161.8 \\
\hline March & 1,958 & 25,851 & - & 1220.3 \\
\hline April & 2,167 & 19,139 & - & 783.2 \\
\hline May & 1,833 & 15,659 & - & 754.3 \\
\hline June & 2,112 & 15,557 & - & 636.6 \\
\hline July & 2,461 & 21,476 & - & 772.6 \\
\hline
\end{tabular}

\begin{tabular}{|c|c|c|c|c|}
\hline August & 2,705 & 22,286 & - & 723.9 \\
\hline September & 2,171 & 31,737 & - & 295.6 \\
\hline October & 2,705 & 56,477 & - & 1987.9 \\
\hline November & 2,968 & 83,501 & - & 2713.4 \\
\hline December & 14,083 & $1,03,617$ & - & 635.8 \\
\hline Total & $\mathbf{3 9 , 0 4 6}$ & $\mathbf{4 , 4 5 , 3 0 0}$ & - & $\mathbf{1 0 4 0 . 4}$ \\
\hline
\end{tabular}

Sources: www.ndtv/india-news/e-visascheme, MoT, IATO Newsletter

* Foreign tourist arrivals.

** A total of 88,162 foreign tourists arrived in the country on e-Tourist Visa (eTV) in January 2016 as compared to 25,023 during the same month in 2015 registering a growth of 252.3 per cent. According to the Ministry of Tourism, this high growth may be attributed to introduction of e-Tourist Visa for 113 countries as against the earlier coverage of 43 countries. United Kingdom occupied the top slot in the top 10 countries availing the facility with 25.37 per cent. The share of the other top countries availing e-TV facility were USA (15.17\%); Russian Fed. (9.58\%); France (6.00\%); Australia (5.25\%); Germany (4.23\%); Canada (4.10\%); China (3.96\%); Republic of Korea (3.72\%) and Ukraine (2.86\%). The New Delhi airport received the highest percentage of foreign tourists with 33.18 per cent. (http://tourismbreakingnews.com/tag/etv/)

\section{Facts from Table-I:}

In 2015

- Highest No. of Foreign tourist receiving month- December $(1,03,617)$

- Lowest No. of Foreign tourist receiving month- June $(15,557)$

In 2014

- Highest No. of Foreign tourist receiving month- December $(14,083)$

- Lowest No. of Foreign tourist receiving month- May $(1,833)$

Highest Growth \% (2014-15) - In the month of November (2713.4\%)

Foreign Tourists Arrivals on e-Tourist Visa (Month-wise 2015 as compared to 2014): 


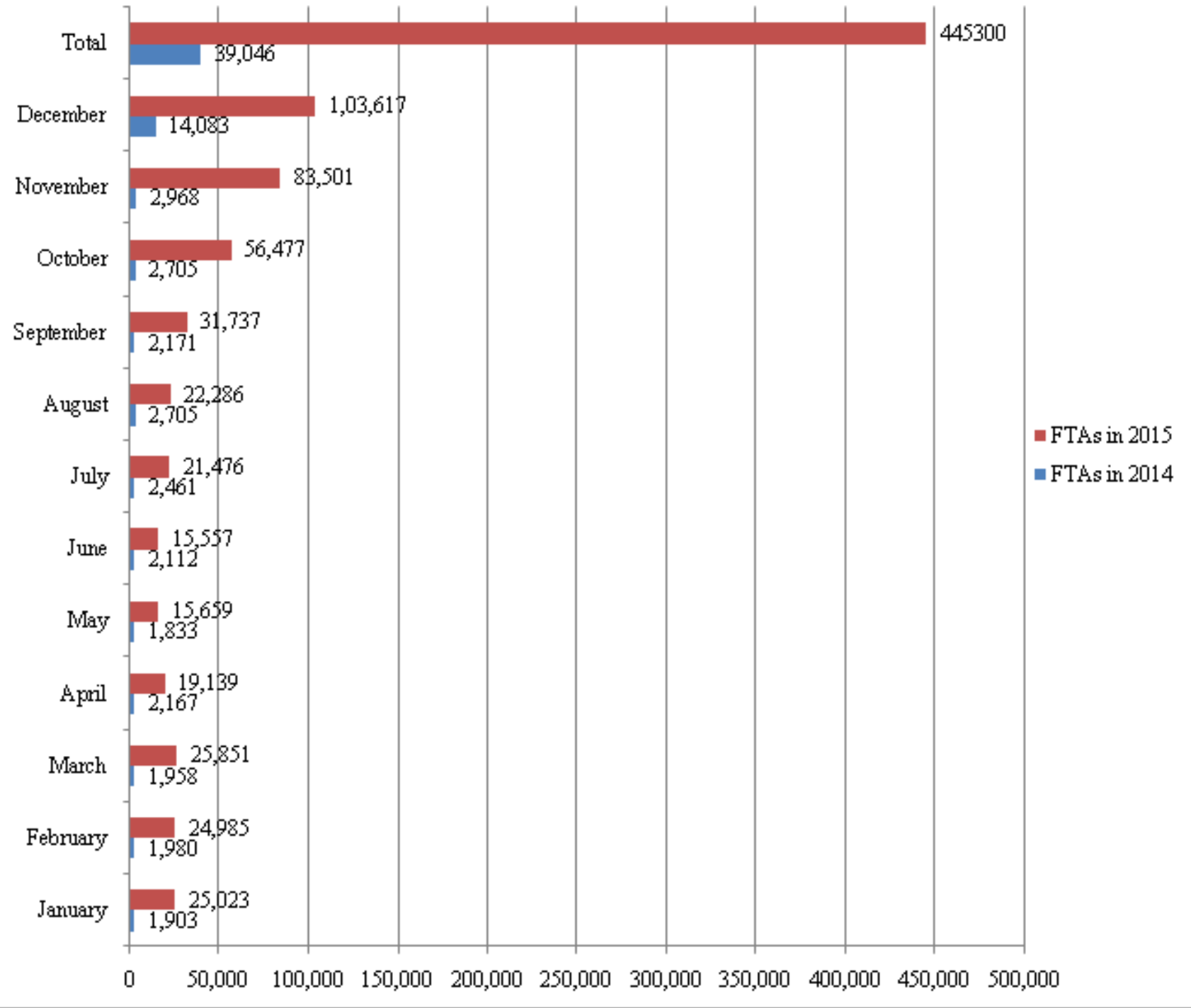

Figure: Trend showing growth of no. of FTAs after reform e-TV from Jan-Dec 2015compared to 2014

\section{Airports share FTAs in 2015:}

In terms of ports, New Delhi Airport had the largest percentage share of $36.23 \%$, followed by Mumbai Airport (21.90\%), Goa Airport (16.54 \%), Bengaluru Airport (5.54 \%), Kochi Airport (4.68 \%), Chennai Airport (4.21\%), Kolkata Airport (2.74 \%), Hyderabad Airport (2.68 per cent), Trivandrum Airport (2.05 per cent) and Ahmadabad Airport $(1.79 \%)^{[11]}$.

\section{Airports share FTAs in 2014:}

During 2014, the Delhi Airport had registered maximum number of FTAs in India i.e. 30.2\% followed by Mumbai airport (19.0\%), Chennai airport (8.8\%), Bengaluru airport (6.3\%), Hyderabad (3.1\%) and Kolkata airport (3.0\%) ${ }^{[12]}$.

Growth \% of Month-wise FTAs after reform e-TV facility for foreign nationals - 
International Journal of Science and Research (IJSR)

ISSN (Online): 2319-7064

Index Copernicus Value (2013): 6.14 | Impact Factor (2014): 5.611

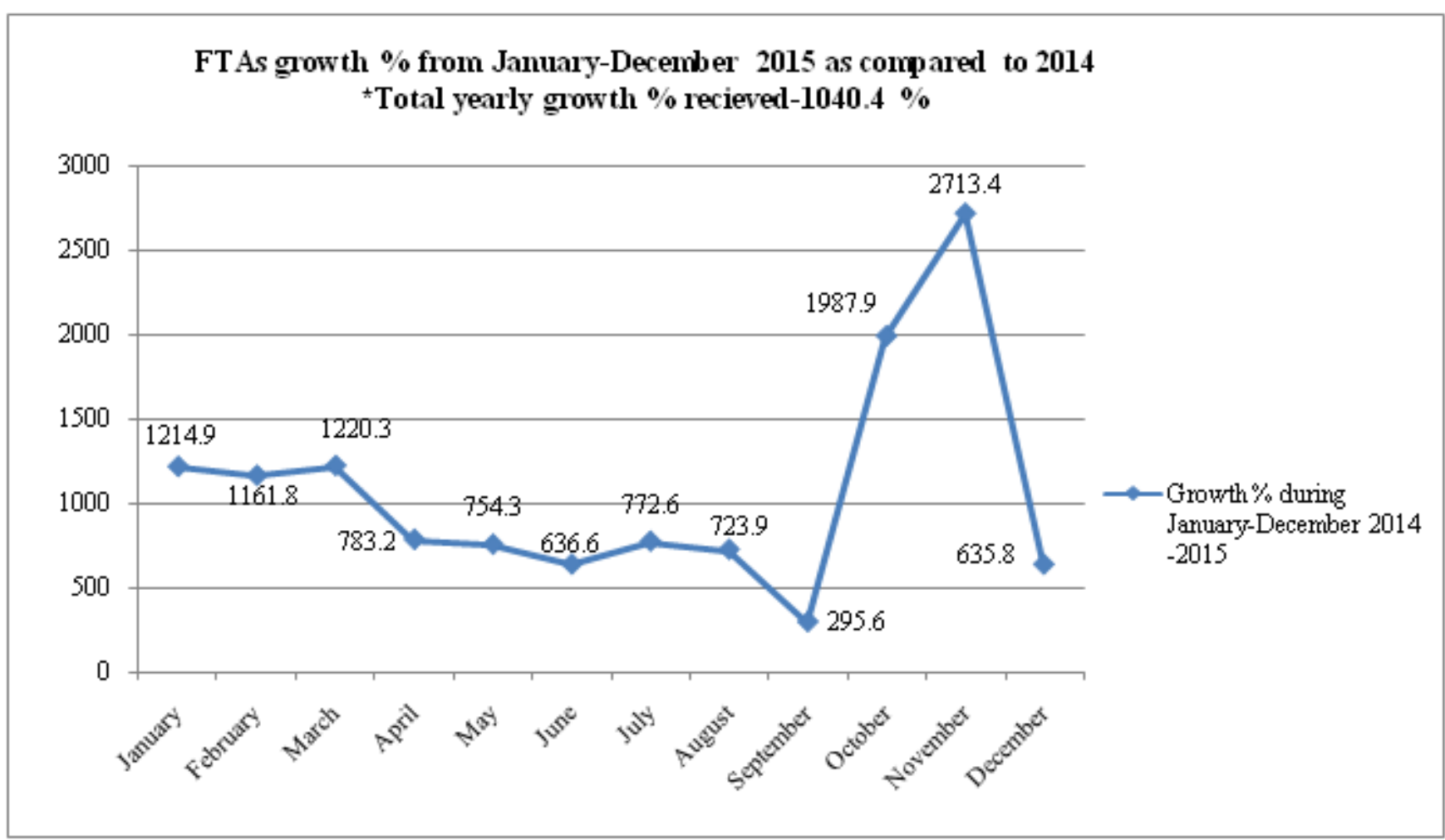

Figure: Trend showing growth \% of FTAs after reform e-TV from Jan-Dec during 2014-2015

*Total growth from (Jan- Dec) of FTAs on e-TV in 2015 as compared to 2014

Table 2: Foreign tourist arrivals by source countries during

\begin{tabular}{|c|c|c|c|c|}
\hline Rank & $\begin{array}{c}\text { Source } \\
\text { countries in } \\
2015\end{array}$ & $\begin{array}{c}\text { Share (in } \\
\%)\end{array}$ & $\begin{array}{c}\text { Source } \\
\text { countries in } \\
2014\end{array}$ & $\begin{array}{c}\text { Share (in } \\
\%)\end{array}$ \\
\hline 1 & UK & 23.81 & US & 14.57 \\
\hline 2 & USA & 19.59 & Bangladesh & 12.27 \\
\hline 3 & Russia & 9.33 & UK & 10.92 \\
\hline 4 & Australia & 5.44 & Sri Lanka & 3.93 \\
\hline 5 & Germany & 4.86 & Russia & 3.51 \\
\hline 6 & France & 4.44 & Canada & 3.50 \\
\hline 7 & Canada & 4.40 & Malaysia & 3.41 \\
\hline 8 & China & 3.10 & France & 3.20 \\
\hline 9 & Korea & 1.83 & Australia & 3.12 \\
\hline 10 & Ukraine & 1.67 & Germany & 3.11 \\
\hline
\end{tabular}

Sources: en.wikipedia.org/wiki/Tourism_in_India, MoT, IATO Newsletter

\section{Results}

During January-December, 2015 a total of 4,45,300 tourist arrived on e-Tourist Visa as compared to 39,046 during January- December, 2014 registering a growth of 1040.4 per cent. This high growth may be attributed to introduction of e-Tourist Visa for 113 countries as against coverage of earlier ETA enabled TVoA scheme for 43 countries. According to Table $-\mathrm{I}$, highest number of tourist arrived in the month of December $2015(1,03,617)$ but the highest growth (2713.4\%) of foreign tourist arrival in the month of November 2015 as comparison to November $2014^{[8]}$ and in the year 2015 minimum tourist arrived in June $(15,557)$ and minimum growth in June 2015 (295.6\%) as compared to June 2014.

\section{Conclusion}

Citizen of all countries require the valid travel documents i.e. passport and valid visa granted by Indian mission abroad for entering India. Visa formalities are a critical issue for visiting in a foreign country. In India, there are many provisions of issuance visa as some long time process earlier but by granting e-Tourist Visa to $140-150$ countries, it have been removed this critical barrier. E-Tourist Visa facility becomes easier to visa formality for foreign citizens who want to visit India. We can conclude results of data by review of literatures in this paper that has widened the horizon of understanding exponential growth in Foreign Visitors incoming in India after expansion of e-Tourist Visa facility. Since launched of the scheme on November 27, 2014 , a total of $1,10,000$ visas have been issued by the government under scheme. The total FTAs during the period January- December 2015 recorded 80.16 lakh with a growth of $4.4 \%$, as compared to the FTAs of 76.79 lakh with a growth of $10.2 \%$ in January- December 2014, in which total FTAs on e- Tourist Visa during January to December 2015 recorded 4.45 lakh with a growth of $1040.4 \%$, as compared to the FTAs on Visa on Arrival in 2014. Indian government announced that it would extend the tourist visa on arrival facility to boost the country's tourism continuously.

\section{References}

[1] Press Information Bureau, MOT, GOI, Achievement/ Initiatives of Ministry of Tourism", September 19, 2014.

[2] https://en.wikipedia.org/wiki/Tourism_in_India\#Visa_p olicy_of_Inda

[3] Sharma Kshitiz, (2014) Introduction to Tourism Management" McGraw Hill Education (India) Pvt. Ltd, New Delhi, Pg. 192

\section{Volume 5 Issue 3, March 2016}




\section{International Journal of Science and Research (IJSR) \\ ISSN (Online): 2319-7064}

Index Copernicus Value (2013): 6.14 | Impact Factor (2014): 5.611

[4] http://www.immihelp.com/visas/

[5] en.wikipedia.org/wiki/Visa_policy_of_India

[6] http://www.mapsofindia.com/my-india/india/e-touristvisa-new-name-for-old-scheme

[7] http://www.ndtv.com/india-news/significant-jump-inforeigners-availing-e-visa-scheme-781036

[8] http://www.indiaodysseytours.com/news/india-toextend-visa-on-arrival-facility-to-180-countries.html

[9] https://indianvisaonline.gov.in/visa/tvoa.html

[10] http://www.financialexpress.com/author/etw-staffmumbai/

[11] http://tourismbreakingnews.com/tag/etv/

[12] Indian tourism statistics 2014, Ministry of Tourism Govt. of India, Pg.- 24 